\title{
Occurrence of sleep-related breathing disorders in patients with chronic urticaria at its asymptomatic or oligosymptomatic stages
}

\author{
Jolanta Perkowska1 , Jerzy Kruszewski ${ }^{1}$, Piotr Gutkowski², Andrzej Chciałowski³ ${ }^{3}$ Krzysztof Kłos $^{1}$ \\ ${ }^{1}$ Department of Infectious Diseases and Allergology, Military Institute of Medicine, Warsaw, Poland \\ ${ }^{2}$ Non-invasive Cardiology and Telemedicine Ward, Military Institute of Medicine, Warsaw, Poland \\ ${ }^{3}$ Military Institute of Medicine, Warsaw, Poland
}

Adv Dermatol Allergol 2016; XXXIII (1): 63-67 DOI: 10.5114/pdia.2015.48052

\begin{abstract}
Introduction: Chronic urticaria (CU), in view of its manifestations (pruritus, wheals), chronic and recurrent nature is very bothersome for patients and significantly influences their quality of life.

Aim: To assess the importance of sleep problems and sleep-related breathing disorders (SRBDs) declared by CU patients, for their quality of life.

Material and methods: Twenty-eight patients with CU at an asymptomatic stage or with minimal symptoms and signs were qualified for the study. In these patients, assessment of urticaria severity, QoL and SRBDs incidence was carried out.

Results: In a questionnaire study (CU-Q2oL), about 54\% of the patients with CU complained of sleeping problems, about $80 \%$ reported significant fatigue and lack of concentration in the daytime. Respiratory polygraphy, an objective measure of sleep-related breathing disorders (SRBDs) demonstrated their higher incidence in patients with CU than in the general population, but these disorders were mild and had no influence on the reduced quality of life of the study patients, compared with a group of patients without SRBDs.

Conclusions: The occurrence of SRBDs was found in $25 \%$ of patients with CU at asymptomatic or oligosymptomatic stages. The SRBDs in those patients were mild, required no treatment and their occurrence did not cause any significant reduction in their quality of life.
\end{abstract}

Key words: chronic urticaria, sleep-related breathing disorders, quality of life, CU-Q2oL, respiratory polygraphy.

\section{Introduction}

Many papers reported a reduction in the quality of life (QoL) in patients with chronic urticaria (CU) [1-4]. The degree of reduction was comparable to that in coronary artery disease and significantly higher than in other dermatological diseases, such as psoriasis or acne [5]. It is stressed that in CU patients the impairment of functions is not only caused by their physical condition but also by psychological factors, such as anger, annoyance, low self-evaluation etc. They can be a direct cause of urticaria wheals dissemination but also can have a significant effect on the emotional and sexual sphere of the patients and can disturb other physiological body functions $[6,7]$.

\section{Aim}

The aim of the study was to assess the importance of sleep problems and sleep-related breathing disorders (SRBDs) declared by CU patients, for their quality of life.

\section{Material and methods}

Twenty-eight patients were qualified for the study, including 14 women and 14 men aged 22-76 years, with $\mathrm{CU}$ at an asymptomatic stage or with minimal symptoms and signs, hospitalized for diagnostic purposes in the Department of Infectious Diseases and Allergology, Military Institute of Medicine, in whom no antihistamines were given for at least 10 days (Tables 1 and 2). In

Address for correspondence: Jolanta Perkowska MD, Department of Infectious Diseases and Allergology, Military Institute of Medicine, 128 Szaserów St, 04-141 Warsaw, Poland, phone: +48 502593 851, e-mail: jperkowska@wim.mil.pl Received: 14.04.2014, accepted: 10.09.2014. 
Table 1. Characteristics of the examined group

\begin{tabular}{|c|c|c|c|c|c|c|c|c|}
\hline \multirow[t]{2}{*}{ The examined group } & \multirow[t]{2}{*}{$N(\%)$} & \multicolumn{2}{|c|}{ Gender } & \multirow{2}{*}{$\begin{array}{c}\text { Age } \\
\text { [years] } \\
x \pm S D\end{array}$} & \multirow{2}{*}{$\begin{array}{c}\mathrm{BMI} \\
{\left[\mathrm{kg} / \mathrm{m}^{2}\right]} \\
x \pm \mathrm{SD}\end{array}$} & \multirow{2}{*}{$\begin{array}{c}\mathrm{AHI} \\
{[n / \mathrm{h}]} \\
x \pm \mathrm{SD}\end{array}$} & \multirow{2}{*}{$\begin{array}{c}\text { Min. saturation } \\
(\%) \\
x \pm S D\end{array}$} & \multirow{2}{*}{$\begin{array}{l}\text { CU-Q2oL } \\
\text { (points) } \\
x \pm S D\end{array}$} \\
\hline & & $\begin{array}{c}\text { Female } \\
n(\%)\end{array}$ & $\begin{array}{l}\text { Male } \\
n(\%)\end{array}$ & & & & & \\
\hline All patients & $28(100)$ & $14(50)$ & $14(50)$ & $42 \pm 15$ & $35.62 \pm 7.24$ & $3.17 \pm 4.24$ & $90.43 \pm 4.17$ & $39.92 \pm 16.77$ \\
\hline Patients with SRBDs & $7(25)$ & $2(7)$ & $5(18)$ & $49 \pm 14$ & $28.73 \pm 4.83$ & $9.91 \pm 2.88$ & $88.00 \pm 3.96$ & $32.67 \pm 20.56$ \\
\hline Patients without SRBDs & $21(75)$ & $12(43)$ & $9(32)$ & $40 \pm 15$ & $37.92 \pm 4.72$ & $0.92 \pm 0.72$ & $91.24 \pm 4.00$ & $42.21 \pm 15.32$ \\
\hline
\end{tabular}

$B M I$ - body mass index, AHI - the number of apnoeas or shallow breathing within 1 h of sleep, CU-Q2OL - Chronic Urticaria Quality of Life Questionnaire.

Table 2. Severity of the urticaria in the examined group

\begin{tabular}{cccc}
\hline $\begin{array}{c}\text { UAS } \\
\text { (points) }\end{array}$ & $\boldsymbol{N}(\%)$ & $\begin{array}{c}\text { Presence of itching } \\
n(\%)\end{array}$ & $\begin{array}{c}\text { Presence of wheals } \\
n(\%)\end{array}$ \\
\hline 0 & $17(61)$ & $0(0)$ & $0(0)$ \\
\hline 1 & $7(25)$ & $7(25)$ & $3(11)$ \\
\hline 2 & $4(14)$ & $4(14)$ & $1(4)$ \\
\hline 3 & 0 & $0(0)$ & $0(0)$ \\
\hline
\end{tabular}

UAS - Urticaria Activity Score (min. - 0, max. - 6 points), 0-lack - no wheal, no itch, 1 - mild < 20 wheal/day, mild itch - still but not intrusive, 2 - moderate -21-50 wheal/day, moderate itch - intrusive but not interfering with normal daily activity or sleep, 3 - severe/intensive > 50 wheal/day or large mingle wheal, increase itch - interfering with normal activity or sleep.

these patients, assessment of urticaria severity, QoL and SRBDs incidence was carried out. Chronic urticaria was recognised based on the $\mathrm{CU}$ definition being in force accepted by EAACI/GA2LEN/EDF/AAI/WAO as appearance of wheals, angioedema, or both for $\geq 6$ weeks [8]

\section{Assessment of CU activity}

Urticaria severity was determined using the Urticaria Activity Score (UAS) [8, 9]. In this test, CU severity is rated on a scale from 0 to 6 points, where 0 means absence of wheals and pruritus, while 6 points mean presence of multiple isolated wheals (> 50/day) or large areas of confluent wheals and intense pruritus disturbing normal activity or sleeping.

\section{Assessment of the quality of life in $\mathrm{CU}$ patients}

The effect of CU on QoL reduction was studied using the Polish version of the Chronic Urticaria Quality of Life Questionnaire (CU-Q2oL) [10]. That questionnaire contains 23 questions and is divided into six domains: 1) pruritus, 2) presence of angioneurotic oedema, 3) daily activity disturbances, 4) sleeping problems, 5) feeling of limitation, and 6) appearance. The questions concerning sleep (questions: 7 - CU influence on the sleep; 11 - difficulty in falling asleep; 12 - wake-up from sleep; 13 - feeling tired during the day because of a bad night sleep) and questions concerning manifestations of feeling bleary (questions: 14 - problems with concentration; 15 - feeling nervous; 16 - bad mood) were subject to particular analysis. The answers to the questions are rated on a five-point scale, from 0 to 4 points, where the higher the score, the greater the influence of CU on QoL reduction.

\section{SRBDs diagnostics}

In order to detect SRBDs, all those patients, after filling in the questionnaire provided in the study, were subjected to respiration monitoring during sleep using the polygraphy method [11]. During the examination, chest and abdomen movements, air flow through the airways, episodes of snoring, blood saturation and heart rate were recorded using an EMBLETTA equipment (Embla, USA). Based on that, the programme calculated the AHI index (number of episodes of apnoea or shallow respiration per hour of sleep), ODI desaturation index and awakening index, qualifying SRBDs to the following categories: central sleep apnoea (CSA), obstructive sleep apnoea (OSA) and mixed sleep apnoea (MSA) [12, 13]. Automatic analysis was checked and corrected accordingly by one of authors (PG). The results were related to the results of the study conducted in Poland on 676 subjects aged 41-72 years, where the criterion of apnoea significance was the same, and sleep breathing disorders were found in $16.7 \%$ of men and $5.4 \%$ of women [14].

The study was approved by the local ethical committee (44/WIM/2012 of 22 September 2012). Written informed consent was obtained from all participants.

\section{Results}

\section{CU severity based on UAS questionnaire}

The arithmetical mean of CU intensity score value according to UAS in the study group was $0.7 \pm 0.1$ points, without any significant differences between women and men. The patients most frequently complained of pruritus of various intensity (moderate or mild). The presence of urticaria wheals was reported by only 4 patients and these were usually isolated eruptions, and only in $1 \mathrm{pa}$ tient, the number of observed wheals was about 20.

\section{Quality of life based on CU-Q2oL questionnaire}

The summary arithmetic mean of the QoL index from the answers to all questions in the questionnaire in the whole study group was $40 \pm 16$ points and showed no 


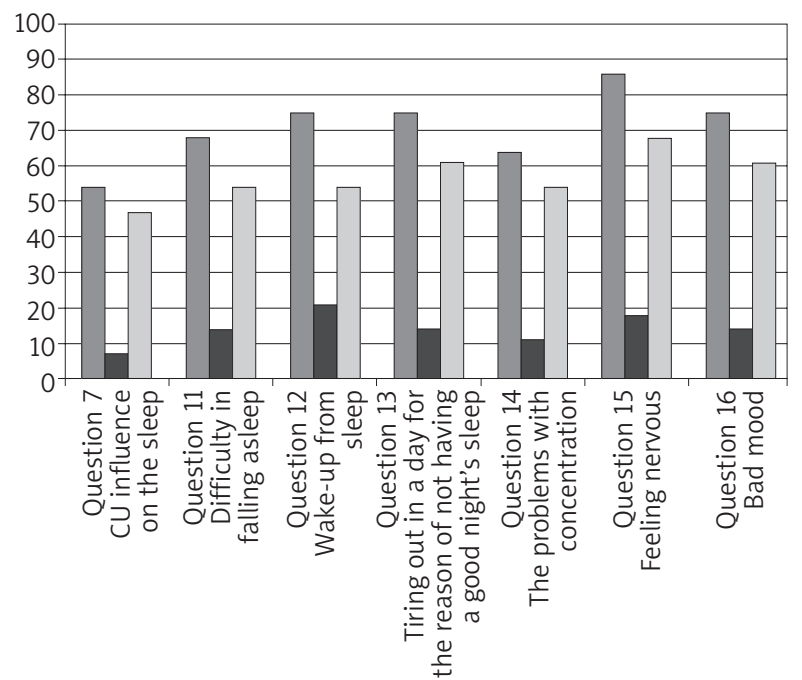

All patients

Patients with SRBDs

Patients without SRBDs

Figure 1. Percentage of the examined patients who answered "yes" to questions concerning the sleep and daytime symptoms of feeling bleary (questions: 7, 11-16 CU-Q2oL)

significant differences between women and men. Only in $21 \%$ of patients, the QoL index did not exceed 23 points and in almost a half (49\%) of the study subjects, it was within the 24-46 point range, in 25\% within the 47-69 point range, and only in $4 \%$ its value exceeded 70 points. In the group with SRBDs, the summary arithmetic mean of the QoL index was $32 \pm 20$ points, while in the group without SRBDs, it was $42 \pm 15$ points but, in spite of arithmetic differences, no statistically significant difference was found between the study groups.

As shown in Figure 1, more than 54\% of the patients replied in the affirmative to the question whether CU caused significant limitations in respect of sleep (question 7 CU-Q2oL), and reported problems of various intensity in this respect. The problem most frequently reported, i.e. by $85 \%$ of the patients, were awakenings from sleep (question 12 CU-Q2oL), which were described by $40 \%$ of the subjects as frequent or very frequent. Almost $68 \%$ of the study subjects reported problems with falling asleep (question 11 CU-Q2oL), which were described by $20 \%$ of the subjects as frequent or very frequent. Daytime symptoms of feeling bleary were reported by most patients. Daytime fatigue (question $13 \mathrm{CU}-\mathrm{Q} 2 \mathrm{OL}$ ) was reported by $75 \%$, including $30 \%$ of the subjects, who described it as frequent or very frequent. Problems with concentration (question 14 CU-Q2oL) were reported by $64 \%$ of the patients. The question: "are you agitated?" (question $15 \mathrm{CU}-\mathrm{Q} 2 \mathrm{OL}$ ) was answered in the affirmative by $85 \%$ of the patients, and that manifestation occurred sometimes or frequently in over half of the patients. Mood depression of various intensity (question $16 \mathrm{CU}-\mathrm{Q} 2 \mathrm{OL}$ ) was reported by $75 \%$ of the patients. As shown in Figure 2, in spite of the differences of the score mean values in individual questions observed

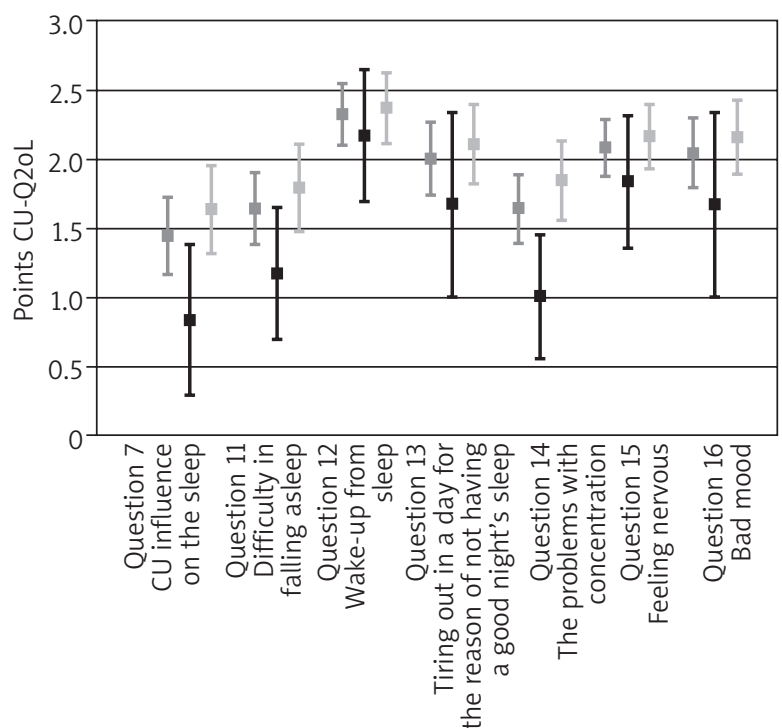

Appropriate numerical values were assigned to replies (the larger the number, the greater the influence CU on the reduced quality of life: 0 - not at all. 1 - mild, 2 - moderate, 3 -strong, 4 - very strong).

Figure 2. The arithmetic mean of points scored from answers to questions concerning the sleep and daytime symptoms of feeling bleary (questions: 7, 11-16 CU-Q2oL**)

Table 3. Incidence of different types of breathing disorders during sleep in the examined group

\begin{tabular}{lc}
\hline Types of sleep-related breathing disorders & $\boldsymbol{N}(\%)$ \\
\hline With SRBDs: & $7(25)$ \\
\hline Central sleep apnoea (CSA) & $0(0)$ \\
\hline Mixed sleep apnoea (MSA) & $5(18)$ \\
\hline Obstructive sleep apnoea (OSA) & $2(7)$ \\
\hline Without SRBDs & $21(75)$ \\
\hline
\end{tabular}

between the groups with and without SRBDs, these values were not found statistically significant.

\section{Sleep-related breathing disorders}

In the study conducted, SRBDs were found in $25 \%$ of the patients with CU, that is in a greater percentage than that found by other researchers in the general population [15]. In 5 study subjects, a mixed type occurred and in 2 cases isolated OSA was found (Table 3). The SRBDs were found more frequently in the study group of men (5 subjects, $18 \%$ ) than women (2 patients, $7 \%$ ). No significant relationship was found between SRBDs occurrence and nocturnal CU disseminations.

\section{Discussion}

As it has been confirmed by the results of the current study, the assessment of CU activity based on ob- 
jective UAS index assessing the presence of pruritus and the number of urticaria wheals may be insufficient for full evaluation of CU influence on all aspects of the patient's life. Therefore, more precise tools were looked for by means of questionnaires assessing the health-related quality of life $[16,17]$. For that purpose, the questionnaires may be applied such as those used in dermatology, e.g. SF36, DLQI, Skindex [18-22]. However, CU-Q2oL is a tool most recommended by the international expert panel under the auspices of the EAACI/GA2LEN/EDF/AAI/ WAO for patients with CU [23].

That questionnaire considers not only the occurrence of manifestations of the dermatological disease, but also its physical, mental and emotional results. This study confirmed the significant effect of urticaria on QoL index worsening, signalled in many papers [1-3]. Declarations of the study patients with CU show that also sleep, an integral part of human health, exerting an important influence on daytime functioning, was disturbed in most study subjects. That has found expression in declaring not only the symptoms directly associated with sleep, but also daytime symptoms which are a consequence of feeling bleary, i.e. daytime fatigue, agitation, difficulties in concentration, mood depression. These, in turn, result in lower efficiency at work or school [7].

It is worth stressing that the procedure of SRBDs evaluation includes also questionnaires for patients concerning certain issues, which are also contained in the CU-Q2oL questionnaire, particularly daytime symptoms of feeling bleary (questions 13, 14, 15 and 16 of CU-Q2oL), daytime fatigue, agitation, reduced concentration. In the study group, these symptoms were reported practically by $80 \%$ of patients, equally in both questionnaires. The differences found in sleep problems (question 7) and falling asleep (question 11) in patients with CU with and without SRBDs, seem to result from the fact that the patients with SRBDs are characterised by increased drowsiness and easiness of falling asleep at night and even in the daytime. The answers to the question concerning awakenings (question $12 \mathrm{CU}-\mathrm{Q} 2 \mathrm{oL}$ ), similar in both groups, suggest that the reported daytime symptoms of feeling bleary resulted rather from frequent awakenings during night (Figures 1 and 2).

The current study suggests that in patients with CU at asymptomatic or oligosymptomatic stages, sleep problems can occur. However, in spite of theoretical premises suggesting a possibility of the influence of mediators determining CU disseminations on various pathophysiological mechanisms and body functions, no papers have been found in the literature taking up the subject of SRBDs occurrence in patients with CU. It is known that histamine, the main mediator of acute urticaria, important also in chronic urticaria, participates under physiological conditions in the process of maintaining wakefulness through its effect on specific receptors in the central nervous system [23]. Its increased release in patients with CU may be responsible for the difficulties in falling asleep or awakenings, as well as for agitation or predisposition to depression [24]. Antihistamines, even second-generation ones, used in the treatment of $\mathrm{CU}$, capable of penetration into the central nervous system and histaminergic system blockade can, in turn, cause sedation [25]. There are studies available, assessing the usefulness of antihistamines in the treatment of insomnia, however those drugs are not recommended and approved in this disease [26]. Taking into account the studies by other authors demonstrating that SRBDs occur in several to over ten percent of the population, it can be said that the percentage of patients with SRBDs found in the current study (25\%) is higher than that in the general population [11, 12]. A relatively high incidence of SRBDs of mixed sleep apnoea (MSA) type, i.e. containing the central and obstructive components, in patients with CU (Table 3) allows to suspect that they could be directly associated with CU and determined by the effects of histamine or other mediators of allergic reactions. The absence of any evident effect of SRBDs occurrence on the quality of life of patients with CU suggests, on the one hand, that, irrespective of their association with the disease, they constitute no significant problem for the patients and, on the other hand, that this situation can cause some difficulties in making initial diagnosis of SRBDs occurrence in patients with CU.

\section{Conclusions}

The occurrence of SRBDs was found in $25 \%$ of patients with CU at asymptomatic or oligosymptomatic stages. SRBDs in those patients were mild, required no treatment and their occurrence did not cause any significant reduction in their quality of life.

\section{Conflict of interest}

The authors declare no conflict of interest.

\section{References}

1. Poon E, Seed PT, Greaves MW, Kobza-Black A. The extent and nature of disability in different urticarial conditions. $\mathrm{Br}$ J Dermatol 1999; 140: 667-71.

2. Żelazny I, Nowicki R, Majkowicz M, et al. Jakość życia w chorobach skóry. Przew Lek 2004; 9: 60-5.

3. Finlay A. Research methodology in quality of life assessment. In: Psychodermatology: the psychological impact of skin disorders. Walker C, Papadopoulos L (eds.). Cambridge University Press, Cambridge 2005; 116-30.

4. Ucmak D, Akkurt M, Toprak G, et al. Determination of dermatology life quality index, and serum C-reactive protein and plasma interleukin-6 levels in patients with chronic urticarial. Adv Dermatol Allergol 2013; 3: 146-51.

5. Tyc-Zdrojewska E, Trznadel-Grodzka E, Kaszuba A. Wpływ przewlekłych chorób skóry na jakość życia pacjentów. Dermatol Klin 2011; 13: 155-60. 
6. Kieć-Świerczyńska M, Kręcisz B, Potocka A, et al. Czynniki psychologiczne w przebiegu chorób alergicznych skóry. Med Pr 2008; 59: 279-85.

7. Brzoza Z. Jakość życia i zaburzenia psychiczne u chorych na przewlekłą pokrzywkę. Przew Lek 2012; 2: 16-7.

8. Zuberbier T, Asero R, Bindslev-Jansen C, et al. EAACI/GA2LEN/EDF/WAO Guideline for the definitions, classification, diagnosis and management of urticarial: the 2013 revision and update. Allergy 2009; 64: 1417-26.

9. Gliński W, Silny W, Czarnecka-Operacz M, et al. Postępowanie diagnostyczno-lecznicze w pokrzywce. Konsensus zespołu specjalistów w dziedzinie dermatologii i wenerologii oraz alergologii. Adv Dermatol Allergol 2007; 24: 1-10.

10. Brzoza Z, Badura-Brzoza K, Mtynek A, et al. Adaptation and initial results of the Polish version of the GA(2)LEN chronic urticaria quality of life questionnaire (CU-Q(2)oL). J Dermatol Sci 2011; 62: 36-41.

11. Pływaczewski R, Brzecka A, Bielicki P, et al. Zalecenia Polskiego Towarzystwa Chorób Płuc dotyczące rozpoznawania i leczenia zaburzeń oddychania w czasie snu (ZOCS) u dorostych. Pneumonol Alergol Pol 2013; 81: 221-58.

12. Chazan R. Klasyfikacja, obraz kliniczny i diagnostyka zaburzeń oddychania w czasie snu. Pneumonol Alergol Pol 2007; 75 (Suppl. 1): 15-9.

13. American Academy of Sleep Medicine - The International Classification of Sleep Disorders. Revised. Diagnostic and Coding Manual. American Academy Sleep Medicine 2005; $1-401$.

14. Pływaczewski R. Częstość i nasilenie zaburzeń oddychania w czasie snu wśród dorosłej populacji prawobrzeżnej Warszawy. Instytut Gruźlicy i Chorób Płuc, Warsaw 2003; 1-291.

15. Baiardini I, Pasquali M, Braido F, et al. A new tool to evaluate the impact of chronic urticaria on quality of life: chronic urticaria quality of life questionnaire (CU-Q2oL). Allergy 2005; 60: 1073-8.

16. Jaeschke R, Guyatt GH, Cook D, Miller J. Określanie i mierzenie jakości życia związanej ze zdrowiem. Med Prakt 1999; 3016: 155-62.

17. Ware JE, Sherbourne CD. The MOS 36-item short-form Health Survey (SF36). Conceptual framework and item selection. Med Care 1992; 30: 437-83.

18. Finlay AY, Khan GK. Dermatology Life Quality Index (DLQI) a simple practical measure for routine clinical use. Clin Exp Dermatol 1994; 19: 210-6.

19. Szepietowski J, Salomon J, Finlay AY, et al. DLQI: Polish version. Dermatol Klin 2004; 6: 63-70.

20. Anderson RT, Rajagopalan R. Development and validation of a quality of life instrument for cutaneous diseases. J Am Acad Dermatol 1997; 37: 41-50.

21. Chren MM, Lasek RJ, Quinn LM, et al. Skindex, a quality-of life measure for patients with skin disease: reliability, validity and responsiveness. J Invest Dermatol 1996; 107: 707-13.

22. Maurer M, Magerl M, Metz M, Zuberbier T. Revisions to the international guidelines on the diagnosis and therapy of chronic urticaria. J Dtsch Dermatol Ges 2013; 11: 971-8.

23. Thakkar MM. Histamine in the regulation of wakefulness. Sleep Med Rev 2011; 15: 65-74.

24. Kano M, Fukudo S, Tashiro A, et al. Decreased histamine $\mathrm{H} 1$ receptor binding in the brain of depressed patients. Eur J Neurosci 2004; 20: 803-10.

25. Belsito DV. Second-generation antihistamines for the treatment of chronic idiopathic urticaria. J Drugs Dermatol 2010; 9: 503-12.

26. Wrona D, Jurkowski KJ, Bobek-Nillewicz B, et al. Neurotransmitery i neuromodulatory snu. Sen 2005; 5: 56-64. 